\title{
MODELLING ANIMAL SYSTEMS PAPER Stochastic simulation of the cost of home-produced feeds for ruminant livestock systems
}

\author{
E. FINNERAN ${ }^{1,2}$, P. CROSSON ${ }^{1}$, P. O' $\mathrm{KIELY}^{1}$, L. SHALLOO ${ }^{3}$, D. FORRISTAL ${ }^{4}$ AND M. WALLACE ${ }^{2}$ \\ ${ }^{1}$ Animal and Grassland Research and Innovation Centre, Teagasc, Grange, Dunsany, County Meath, Republic of Ireland \\ ${ }^{2}$ School of Agriculture, Food Science and Veterinary Medicine, University College Dublin, Belfield, Dublin 4, \\ Republic of Ireland \\ ${ }^{3}$ Animal and Grassland Research and Innovation Centre, Teagasc, Moorepark, Fermoy County Cork, Republic of Ireland \\ ${ }^{4}$ Crops Research Centre, Teagasc, Oakpark, Carlow, County Carlow, Republic of Ireland
}

(Received 3 November 2010; revised 1 June 2011; accepted 23 June 2011; first published online 22 July 2011)

\section{SUMMARY}

An agro-economic simulation model was developed to facilitate comparison of the impact of management, market and biological factors on the cost of providing ruminant livestock with feed grown on the farm (home produced feed). Unpredictable year-to-year variation in crop yields and input prices were identified as quantifiable measures of risk affecting feed cost. Stochastic analysis was used to study the impact of yield and input price risk on the variability of feed cost for eight feeds grown in Ireland over a 10-year period. Intensively grazed perennial ryegrass was found to be the lowest cost feed in the current analysis (mean cost $€ 74 / 1000$ Unité Fourragère Viande (UFV)). Yield risk was identified as the greatest single factor affecting feed cost variability. At mean prices and yields, purchased rolled barley was found to be $3 \%$ less costly than home-produced spring-sown barley. However, home-produced spring barley was marginally less risky than purchased barley (coefficient of variation (CV) 0.063 v. 0.064). Feed crops incurring the greatest proportion of fixed costs and area-dependent variable costs, including bunker grass silage, were the most sensitive to yield fluctuations. The most energy inputintensive feed crops, such as grass silage, both baled and bunker ensiled, were deemed most susceptible to input price fluctuations. Maize silage was the most risky feed crop (CV 0.195), with potential to be both the cheapest and the most expensive conserved feed.

\section{INTRODUCTION}

For livestock farmers, one of the most important groups of management decisions is that relating to feed provision. McCall \& Clark (1999) identified feed cost as the primary issue determining the choice of dairy system in North Eastern USA and New Zealand, while in Australia Archer et al. (1999) described feed cost as the greatest input cost group in any animal production system. Feed cost accounts for $0 \cdot 70-0.75$ of all variable costs incurred on Irish cattle and sheep farms (Connolly et al. 2010). Furthermore, fixed costs associated with feed production and utilization, such as silos, fencing, buildings and machinery, are an additional consideration when costing alternative feeds (Fluck \& Peart 2004). Given that feed cost constitutes such a

* To whom all correspondence should be addressed. Email: paul. crosson@teagasc.ie large proportion of total cost, it is clear that effective management of feeding strategy decisions can greatly contribute to the economic sustainability and profitability of livestock farms.

Recent volatility in market prices resulting in increased uncertainty of input and output prices, changes in agricultural policy and the continual development of new agronomic technologies and feeding systems have all been identified as factors contributing to increased complexity in the decisionmaking process for livestock farmers (Cros et al. 2004; Shalloo et al. 2004; Belasco et al. 2009; Finneran et al. 2010b).

Computer models have been extensively used to model the interactions between biological and management variables influencing crop production (McCown et al. 1996; Shaffer et al. 2000; Jones et al. 2003; Dobos et al. 2004). Fewer studies used models 
to simulate the impact of such interacting management and biological variables on the costs of producing ruminant feed crops. Savoie et al. (1985) modelled the impact of weather variation and the use of new feed cropping technologies on the profitability of a US dairy system. Neal et al. (2007) used an optimization model to identify the economically optimal combination of feed crops to produce for an Australian dairy system. O'Kiely et al. (1997) examined the impact of yield and utilization factors on feed crop cost, calculated independently of a livestock production system. However, none of these studies conducted risk analysis to analyse the sensitivity of different feed crops to yield or price fluctuations; they also used partial-costing approaches by omitting some important cost components. Savoie et al. (1985) and Neal et al. (2007) omitted an opportunity cost for land from their total feed cost (TFC), while Savoie et al. (1985) did not include the cost of fixed facilities required for feed storage or the cost of on-farm labour.

An agro-economic simulation model, the Grange Feed Costing Model (GFCM @ T Teagasc 2010), was developed to better inform research, extension and farmers of the complex interactions of the many variables affecting feed cost. The objectives of the current paper are: (1) to describe the modelling approach and costing methodology used in the GFCM, (2) quantify the cost of producing and utilizing ruminant feed crops and (3) evaluate the risk associated with yield and input price fluctuations for each of these feed crops.

\section{MODEL DESCRIPTION}

The GFCM was developed as a steady state, spreadsheet-based, agro-economic simulation model for evaluation of the physical and financial performance of feed crop production and utilization options in Ireland (Finneran et al. 2010b). In the GFCM and for the purposes of the current paper 'feed crop production' refers to all processes from land preparation, sowing and crop management through to the point of grazing or harvest. 'Utilization' refers to all management-controlled processes from immediately prior to harvest through to the point of ingestion by an animal, including grazing or mechanical harvesting, processing, conservation, storage and feed-out operations.

Table 1 lists the range of home-produced feed crops (or crop combinations) for which production and feed cost can be simulated by the GFCM. Taking the feed crop production and utilization (harvest, conservation and feed-out technologies) options into account, 68 distinct feed cropping scenarios can be simulated by the GFCM.

\section{Costing conventions and TFC specification}

The GFCM quantifies crop output $(O)$ in a range of measures including dry matter available to be harvested per crop hectare ( $\mathrm{kg} \mathrm{DM} / \mathrm{ha}$ ), utilized dry matter per crop hectare ( $\mathrm{kg} U \mathrm{UM} / \mathrm{ha})$, digestible dry matter per crop hectare ( $\mathrm{kg} \mathrm{DDM} / \mathrm{ha})$, metabolizable energy per crop hectare, expressed as mega joules (ME/ ha) and net energy per crop hectare (NE/ha). The net energy system used is that described by Jarrige (1989), where Unité Fourragère Lait (UFL) is the unit measure of net energy for maintenance and lactation and Unité Fourragère Viande (UFV) is the unit measure of net energy for maintenance and meat production. One UFL is equivalent to the net energy for maintenance and lactation available from $1 \mathrm{~kg}$ of air-dried rolled barley; similarly, one UFV is equivalent to that required for maintenance and meat production from $1 \mathrm{~kg}$ of air-dried rolled barley. The GFCM does not specify an animal component. The simulated system terminates prior to the point of ingestion of the feed crop by a ruminant. By focusing solely on the production, conservation and feed-out of feed crops, the range of ruminant production systems for which GFCM results are applicable is broadened.

The GFCM employs a full costing approach in calculating the TFC of each feed crop (Eqn (1)). TFC is equivalent to the 'economic cost'; i.e. 'accounting cost', plus the opportunity cost of the resources employed (Kay \& Edwards 1994). The accounting cost includes all variable and fixed production, processing, storage and feed-out costs associated with the feed crop, in addition to depreciation and interest on capital funding of fixed assets.

$\mathrm{TFC}_{i}=\left(\mathrm{VCWC}_{i}+\mathrm{FC}_{i}+\mathrm{LC}_{i}\right) / O_{i}$

where $\mathrm{TFC}_{i}$ is the total feed cost of feed crop $i(€ /$ unit $O), O_{i}$ is the output of feed crop $i, \mathrm{VCWC}_{i}$ is the total variable costs (including working capital) per hectare associated with the production and utilization of feed crop $i, \mathrm{FC}_{i}$ is the total fixed costs per hectare associated with the production and utilization of feed crop $i, \mathrm{LC}_{i}$ is the land charge attributed to feed crop $i(€ / h a)$.

Land is generally the most limiting resource constraining production and utilization of a feed crop in pasture-based production systems (Visscher et al. 1994). The opportunity cost of the land employed in 
Table 1. Crop types, sowing options and utilization options in the GFCM

\begin{tabular}{|c|c|c|c|c|c|c|}
\hline & Crops species/species mixes & Sowing options & $\begin{array}{l}\text { No. of } \\
\text { grazing } \\
\text { options* }\end{array}$ & $\begin{array}{l}\text { No. of } \\
\text { silage } \\
\text { optionst }\end{array}$ & $\begin{array}{l}\text { No. of } \\
\text { other } \\
\text { harvest } \\
\text { options } \neq\end{array}$ & $\begin{array}{l}\text { No. of } \\
\text { post-harvest// } \\
\text { conservation } \\
\text { options§ }\end{array}$ \\
\hline \multirow{3}{*}{$\begin{array}{l}\text { Ryegrasses } \\
\text { and legumes }\end{array}$} & Perennial ryegrass (Lolium perenne) & \multirow{3}{*}{$\begin{array}{l}\text { User defined } \\
\text { re-seeding } \\
\text { interval }\end{array}$} & 1 & 4 & 2 & - \\
\hline & $\begin{array}{l}\text { Perennial ryegrass and white clover } \\
\text { (L. perenne/ Trifolium repens) }\end{array}$ & & 1 & - & - & - \\
\hline & $\begin{array}{l}\text { Perennial ryegrass and red clover } \\
\text { (L. perenne/ Trifolium pratense) }\end{array}$ & & 2 & $4 a$ & - & - \\
\hline \multirow[t]{5}{*}{ Cereals } & Wheat (Triticum aestivum) & \multirow[t]{4}{*}{ Winter or spring } & - & 2 & $2 \mathrm{a}$ & 4 \\
\hline & Barley (Hordeum sativum) & & - & 2 & $2 \mathrm{a}$ & 4 \\
\hline & Oats (Avena sativa) & & - & 2 & $2 \mathrm{a}$ & 4 \\
\hline & Triticale (Triticum triticosecale) & & - & 2 & $2 \mathrm{a}$ & 4 \\
\hline & Maize (Zea mays) & Mulch/no mulch & - & 1 & - & - \\
\hline \multirow[t]{4}{*}{ Brassicas } & Kale (Brassica oleracea) & \multirow{4}{*}{$\begin{array}{l}\text { Multiple sowing } \\
\text { date options }\end{array}$} & 1 & - & - & - \\
\hline & Swedes (Brassic napobrassica) & & 1 & - & - & - \\
\hline & $\begin{array}{l}\text { Stubble turnips (Brassica rapa ssp. } \\
\text { oleifera) }\end{array}$ & & 1 & - & - & - \\
\hline & Fodder rape (Brassica napus) & & 1 & - & - & - \\
\hline \multirow[t]{2}{*}{ Beet } & Fodder beet & \multirow[t]{2}{*}{ April sown } & 1 & - & 1 & - \\
\hline & Sugar beet (Beta vulgaris ssp.vulgaris) & & 0 & - & 1 & - \\
\hline
\end{tabular}

* 1. Grass rotationally grazed over a full grazing season. 2 . Ryegrass and red clover swards may be grazed following either the second or third silage harvest.

+ 1. Maize harvested as whole-crop fermented silage. 2. Small grain cereal crops may be harvested as whole crop for fermented silage or high $\mathrm{pH}$ alkalage. 4. Baled or bunker silage as either a single harvest or two harvest system. 4a. Baled or bunker silage as either a two-harvest or three-harvest system.

₹ 1. Beet tops may be grazed in situ post root harvest. 2. Grass hay may be conserved as a single-harvest or two-harvest system. 2a. Small grain cereals may be harvested as 'high moisture grain' or 'dry' (>800 g/kg DM) grain.

$\S 4$. Harvested cereal grain may be dried and rolled or conserved via one of three 'high moisture grain' conservation treatments.

the growing and utilization of each feed crop is included as a land charge (LC) in the TFC to give the full economic cost of the feed crop. The LC is based on the prevailing rental market price for productive agricultural land for a 365-day-year, and is a proportion thereof, depending on the length of the feed crop production period (CPP). For annual feed crops, CPP is the time interval between seedbed preparation for the simulated crop and seedbed preparation for the subsequent land use. CPP is fixed as a 365-day-year for the grazed grass swards. For grass silage, LC is apportioned to the crop based on the length of time between the date of final defoliation prior to harvest (closing date) and harvest date, calculated as:

$$
\mathrm{LC}_{\mathrm{GS}}=((\mathrm{H}-\mathrm{C}) / 365) \times \mathrm{LC}
$$

where $\mathrm{LC}_{\mathrm{GS}}$ is the land charge apportioned to the grass silage crop (€/ha), $\mathrm{H}$ is the harvest date, $\mathrm{C}$ is the closing date (default as 1 January for 'not spring grazed' crops), LC is the annual land charge (€/ha).

\section{Variable costs}

The labour, energy and machinery costs involved in producing and utilizing each feed crop are addressed in the GFCM by assuming contractor charges and work rates for all cropping and feeding operations; e.g. tilling, sowing, fertilizing, spraying, harvesting, processing and feed-out (CSO 2010a; O'Mahony \& O'Donovan 2010). Other variable inputs including fertilizers, plant protection products (PPP; including fungicides, growth regulators, herbicides and insecticides), plastics and general labour are costed as per current market prices (CSO 2010a; O'Mahony \& O'Donovan 2010). Variable input costs are assumed to be funded by working capital in the form of savings foregone and calculated in TFC as follows:

$\mathrm{WC}_{i}=\left(\mathrm{VC}_{i} \times\left(\mathrm{CPP}_{i} / 365\right) \times 0.5\right) \times \mathrm{DI}$

where $W_{C}$ is the working capital cost $(€ /$ ha) for feed crop $i, \mathrm{VC}_{i}$ is the total variable costs $(€ / \mathrm{ha})$ for feed crop $i, \mathrm{CPP}_{i}$ is the length of feed crop $i$ production period in 


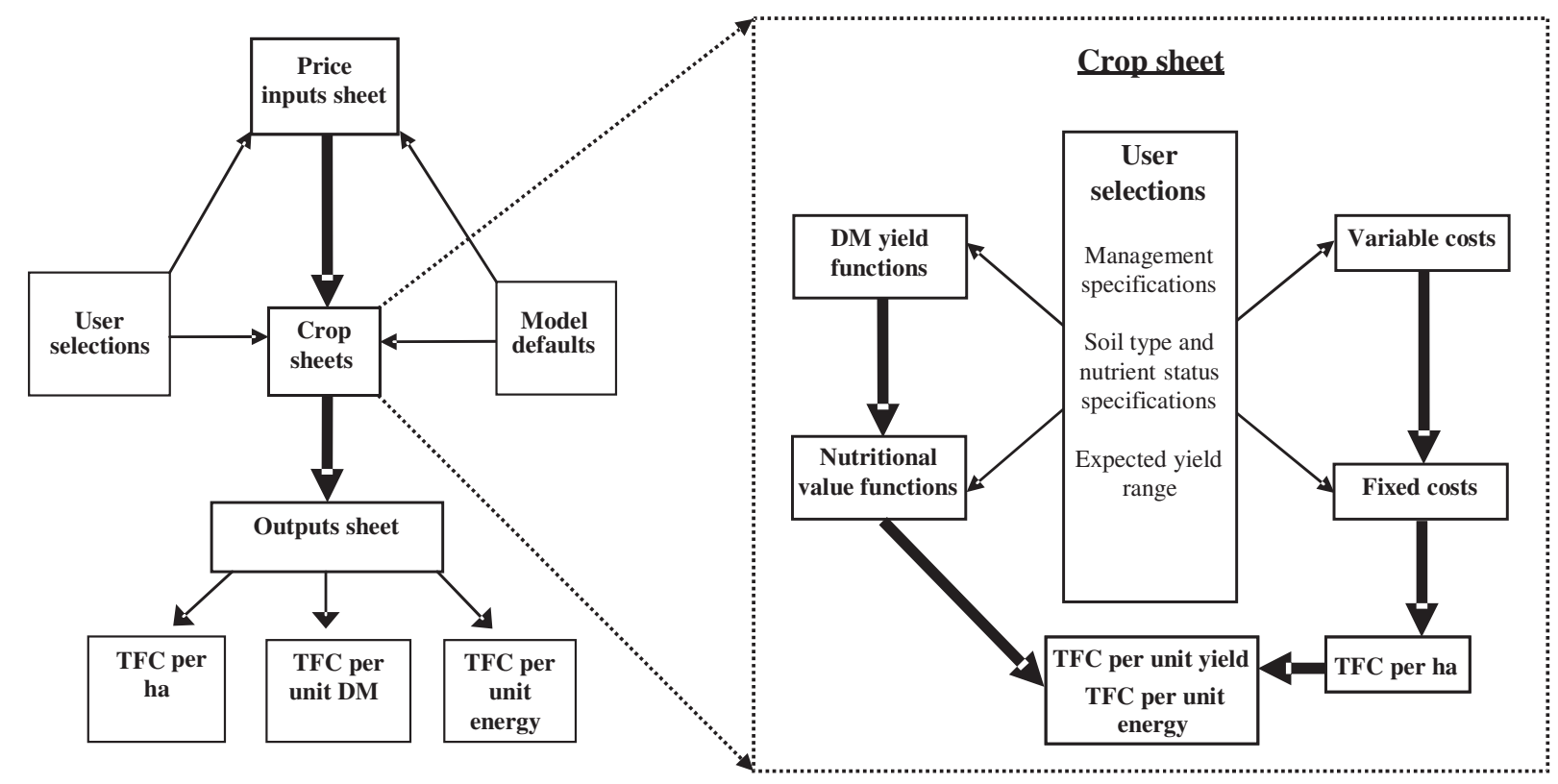

Fig. 1. Schematic of GFCM model structure illustrating TFC calculation.

days and $\mathrm{DI}$ is the annual deposit interest rate in a savings account.

Since variable input costs accumulate throughout the production period rather than all being incurred simultaneously, working capital is multiplied by a factor of 0.5 to approximate the average outlay over the period. The cost of annual maintenance and repair of fixed assets is charged at $0 \cdot 01$ of the construction cost per year (Fluck \& Peart 2004).

\section{Fixed costs}

Fixed costs for each feed crop include the annual depreciation and interest cost of fixed facilities such as fencing, roadways, silos and grain stores. Fixed assets are depreciated over a specified period (e.g. 20 years default for silos and buildings), using the declining balance method. For depreciation calculation purposes, fixed assets are assumed to be at the mid-point of their productive lifetime. If use of a fixed asset is shared between two or more feed crops, e.g. grass silage and grazed grass sharing the field fencing cost, then the cost of that asset is attributed to these crops in proportion to their usage of the asset. Asset usage is apportioned on a volume-by-time basis for storage facilities (e.g. grain store accommodating both wheat and barley grain (BG)) and an areaby-time basis for field utilities such as roadways and fencing. Fixed costs are assumed to be funded by borrowing.

\section{TFC calculation}

A series of mathematical functions use default model coefficients and user specified variables such as sowing date, harvest date, etc. to predict the yields, utilization, nutritional values and subsequently TFC for each feed cropping scenario (see Appendix, available online at http://cambridge.journals.org/AGS). The model is further described in Finneran et al. (2010b). The GFCM crop sheets then summarize the output of the feed crop in the units described above (Fig. 1). TFC is expressed in Euro $(€)$ per ha and per unit output expressed as UDM, DDM, NE and ME as defined above.

\section{MODEL EVALUATION}

In order to ensure that model outputs would provide a reasonable representation of reality, an evaluation process was undertaken to assess the functionality of the model and the appropriateness of data sources used and assumptions made. As no broad and robust dataset of yields and input rates for feed crops grown on Irish farms was available which could be used to validate the model, an assessment of 'face validity' of the GFCM by knowledgeable individuals was conducted as described by Qureshi et al. (1999). Separate group meetings of specialist agricultural advisors and crop and ruminant nutrition researchers were held to evaluate the GFCM development and functionality. Following thorough examination of the individual 


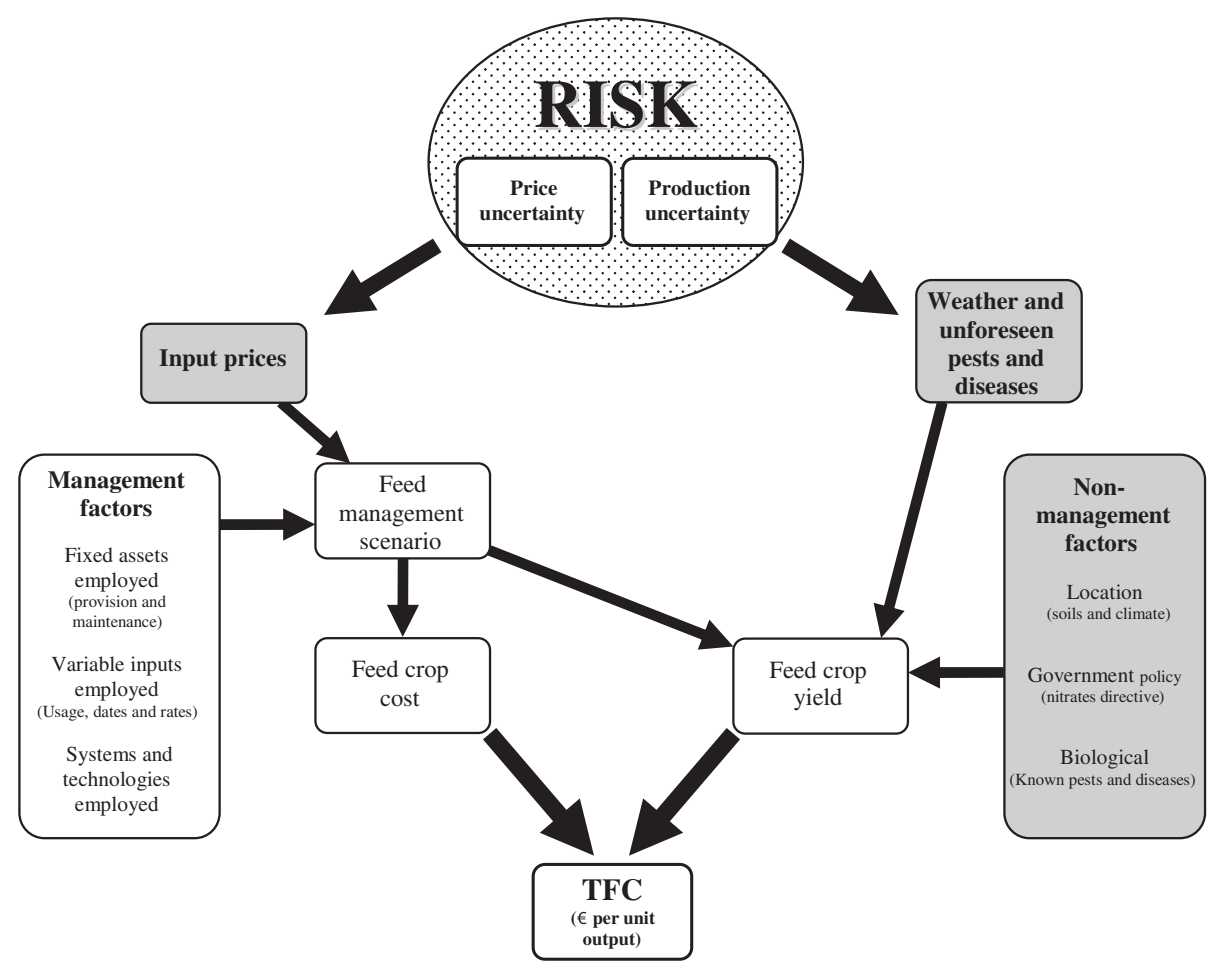

Fig. 2. Sources of price and yield risk affecting TFC.

yield and nutritional value functions, input prices and scenario analysis, it was deemed that the GFCM provided an appropriate model for the interactions influencing feed crop cost on Irish farms.

\section{PRODUCTION AND PRICE RISK}

Farmers are motivated by a range of goals including, but not limited to, profit maximization (Wallace \& Moss 2002). Cros et al. (2004) noted that, because crop yields and livestock production are highly subject to uncontrollable variations as a result of weather and disease, farming systems are more inherently risky than industrial production systems. Increasing variability in input prices (Connolly et al. 2010; USDA 2010) has added to the overall risk function for farmers in recent years. Pannell et al. (2000) found that the inherent greater risk associated with farming could explain the greater risk averseness attributed to farmers relative to industrial production managers. As noted by Pannell et al. (2000) and Lien et al. (2007), farmers' choices among alternative production systems are strongly influenced by their personal attitudes to risk coupled with their perceptions of the relative riskiness of each of those systems. Consequently, models that also quantify the financial risks for individual systems may be much more useful for farmer decision-making than those that focus solely on mean or modal outcomes.

\section{Risk in the GFCM}

The full set of variables influencing feed cost can be categorized as either management factors or nonmanagement factors (Fig. 2). The first group includes management decisions such as the choice of crop, the timing of sowing and harvest, rates of fertilizers and PPPs used, as well as choice of technologies in relation to crop varieties, machinery type, conservation and feed-out, which all affect both feed crop yield and expenditure and consequently feed cost. Nonmanagement factors are those outside the control of the farmer and include government policy, soil type and fertility, latitude, altitude, aspect, climate, pests and diseases, weather variation and market factors (shaded elements in Fig. 2). Certain management actions can be taken to minimize any detrimental impact on crop yield or cost of some of these non-management factors. For example, land location, soil type and climate are known and relatively fixed constraints, and while their fundamental properties cannot be changed by the farmer, management actions can be adjusted to limit the potentially negative effect of these constraints on yield or expenditure. Furthermore, government policy 
changes are often signalled in advance, allowing adjustments to be made at farm level, while anticipated pests and diseases can be effectively controlled by the implementation of appropriate pest and disease control strategies. Therefore, weather, unforeseen pests and diseases and input price uncertainty remain as the variables affecting feed crop production and cost that may be neither predicted nor controlled by the farmer. The analysis undertaken for the current paper aimed to quantify the effect on feed cost of the unpredictable and uncontrollable risks surrounding year-to-year yield and input price variation (i.e. production and price risk). Technological changes or management changes (such as those reported by Finneran et al. 2010b) were not simulated in the current analysis.

\section{Stochastic analysis of input prices and crop yields}

Hardaker et al. (2004) defined uncertainty as imperfect knowledge and risk as uncertain consequences of the outcome of a particular event and outlined a range of analytical approaches for modelling risk. These methodologies were based on the premise that historical ranges of outcomes of uncertain events can provide a satisfactory guide to likely variability of future outcomes. Stochastic budgeting in order to calculate the likelihood of specified scenarios occurring was considered as a powerful planning tool for quantifying risk in agricultural production systems (Hardaker et al. 2004). Stochastic analysis using @RISK software (Palisade Corporation: http://www.palisade. com/risk/, verified 8 June 2011) for MS Excel was employed in the GFCM to analyse the effect of price and production risk on the TFC of a range of commonly grown ruminant feed crops. @RISK employs the Monte Carlo sampling technique of taking a specified number of iterative samples (10000 iterations used in the current study) from the input variable distributions and simulating outputs for each sample. Taking this sufficiently large number of iterations ensures a satisfactory level of convergence; whereby additional iterative simulations make insignificant differences to the estimated moments of the simulated output distributions (Hardaker et al. 2004).

Stochastic budgeting was used to model eight feeds with respect to the impact of yield and price risk on TFC variability. Cumulative density functions (CDFs) for TFC of each of the feeds were generated using the results of the simulations (Fig. 3). These CDFs are graphical representations of the probability of a specific TFC value occurring for each individual feed.

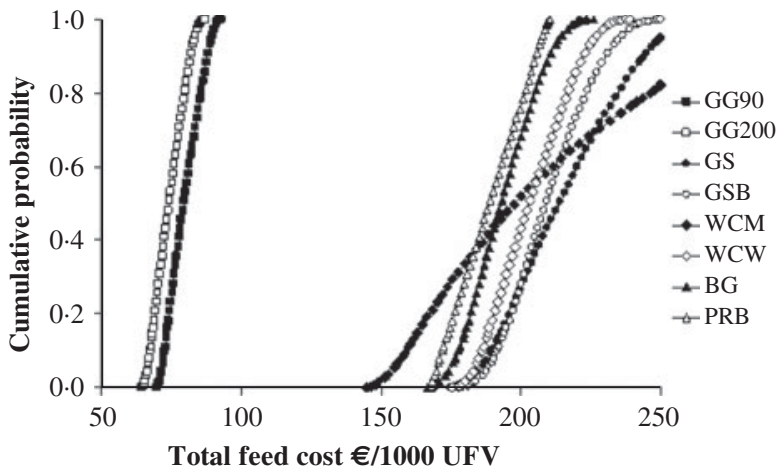

Fig. 3. TFC CDFs indicating input price and yield risk for eight feeds for the years 1999-2008.

Input price data

The modelling of input price data distinguishes a deterministic component and a stochastic component for each price series. Namely, the inflation trend is considered deterministic, while the year-to-year fluctuation around that trend is the stochastic component. The long-run inflation trend is reasonably consistent over time. However, the degree of stochastic price fluctuation around the trend is influenced by unpredictable market factors and determines the level of price risk. The analysis in the current paper attempts to isolate this price risk by removing the deterministic trend component from each input price series as follows. Each input price series, comprising annual data for the years 1999-2008 (CSO 2010a), was regressed on a time trend $(t)$. Using this estimated ordinary least squares regression equation, the trend price $\left(\alpha_{i t}\right)$ was calculated for each input for each year. The residual $\left(\varepsilon_{i t}\right)$ was calculated as the observed price minus the trend price $\left(\alpha_{i t}\right)$ for year $t(t=1, \ldots, 10)$. The residual was then expressed proportionally to the trend price for each individual year, as follows, to give the relative deviation from the 10-year trend:

$\mathrm{DP}_{i t}=\left(\varepsilon_{i t} / \alpha_{i t}\right)(t=1, \ldots, 10)$

where $\mathrm{DP}_{i t}$ is the relative deviation of input price $i$ in year $t$ from the trend price $\left(\alpha_{i t}\right)$ for that input in year $t$.

Fitting the deviation values to the current mean price (2010) for the input provides a stochastic price series that removes the deterministic trend but retains the stochastic fluctuation around the mean price level. Each constructed series provides the input parameters (states) necessary to establish a discrete probability distribution for that input price. The discrete price distributions simulated for each of the 10 years are shown in Table 2. The exceptions to 
Table 2. Ten-year input price deviations and yield distributions simulated for stochastic analysis

\begin{tabular}{|c|c|c|c|c|c|c|c|c|c|c|c|}
\hline \multirow[b]{2}{*}{ Distribution } & \multirow[b]{2}{*}{ Units } & \multicolumn{10}{|c|}{ Year } \\
\hline & & 1999 & 2000 & 2001 & 2002 & 2003 & 2004 & 2005 & 2006 & 2007 & 2008 \\
\hline $\begin{array}{l}\text { Price of purchased dried rolled barley } \\
\text { (bulk delivered) }\end{array}$ & $\begin{array}{l}\text { Deviation from } \\
10 \text { year trend }\end{array}$ & $0 \cdot 081$ & $0 \cdot 041$ & $0 \cdot 007$ & $-0 \cdot 022$ & $-0 \cdot 046$ & $-0 \cdot 026$ & $-0 \cdot 125$ & $-0 \cdot 106$ & $0 \cdot 115$ & $0 \cdot 085$ \\
\hline Price of inorganic $\mathrm{N}$ fertilizer & $\begin{array}{l}\text { Deviation from } \\
10 \text { year trend }\end{array}$ & -0.047 & $-0 \cdot 014$ & $0 \cdot 087$ & $0 \cdot 005$ & $-0 \cdot 027$ & -0.032 & $0 \cdot 009$ & $0 \cdot 035$ & $0 \cdot 011$ & -0.029 \\
\hline $\begin{array}{l}\text { Price of inorganic } \mathrm{P} \text { and } \mathrm{K} \text { compound } \\
\text { fertilizers }\end{array}$ & $\begin{array}{l}\text { Deviation from } \\
10 \text { year trend }\end{array}$ & $0 \cdot 005$ & $0 \cdot 013$ & $0 \cdot 029$ & $-0 \cdot 010$ & $-0 \cdot 020$ & $-0 \cdot 035$ & $-0 \cdot 025$ & $0 \cdot 002$ & $0 \cdot 042$ & $0 \cdot 930$ \\
\hline Price of agricultural contractor charges & $\begin{array}{l}\text { Deviation from } \\
10 \text { year trend }\end{array}$ & -0.008 & $0 \cdot 045$ & $0 \cdot 012$ & -0.016 & $-0 \cdot 032$ & -0.026 & $0 \cdot 005$ & $0 \cdot 010$ & $-0 \cdot 008$ & $0 \cdot 019$ \\
\hline Price of PPP & $\begin{array}{l}\text { Deviation from } \\
10 \text { year trend }\end{array}$ & $0 \cdot 001$ & $-0 \cdot 008$ & $-0 \cdot 002$ & $0 \cdot 003$ & $0 \cdot 000$ & $0 \cdot 013$ & $0 \cdot 006$ & $-0 \cdot 006$ & $-0 \cdot 009$ & $0 \cdot 002$ \\
\hline Deposit account interest rates & $\begin{array}{l}\text { Annual percentage } \\
\text { rate }\end{array}$ & 1.93 & $3 \cdot 18$ & $3 \cdot 44$ & $2 \cdot 32$ & $1 \cdot 31$ & $1 \cdot 05$ & $1 \cdot 05$ & $1 \cdot 84$ & $2 \cdot 62$ & $3 \cdot 15$ \\
\hline $\begin{array}{l}\text { Fixed interest rates on term loans for small } \\
\text { businesses }\end{array}$ & $\begin{array}{l}\text { Annual percentage } \\
\text { rate }\end{array}$ & $5 \cdot 46$ & $6 \cdot 65$ & $7 \cdot 00$ & $7 \cdot 00$ & $7 \cdot 00$ & $7 \cdot 00$ & $7 \cdot 00$ & $7 \cdot 00$ & $7 \cdot 00$ & $6 \cdot 80$ \\
\hline $\begin{array}{l}\text { DM yield of grazed perennial ryegrass } \\
\text { receiving } 90 \mathrm{~kg} \mathrm{~N} / \text { ha per year }\end{array}$ & kg DM/ha & 9851 & 9299 & 10691 & 9276 & 8398 & 9101 & 8847 & 8720 & 9596 & 9739 \\
\hline $\begin{array}{l}\text { DM yield of grazed perennial ryegrass } \\
\text { receiving } 200 \mathrm{~kg} \mathrm{~N} / \text { ha per year }\end{array}$ & kg DM/ha & 12809 & 12092 & 13903 & 12063 & 10921 & 11835 & 11505 & 11339 & 12478 & 12666 \\
\hline $\begin{array}{l}\text { DM yield of perennial ryegrass sward cut } \\
\text { for first harvest silage on } 5 \text { Jun }\end{array}$ & kg DM/ha & 4817 & 6015 & 5748 & 4640 & 4794 & 4715 & 4372 & 5285 & 4768 & 5141 \\
\hline DM yield of WCM cut for fermented silage & kg DM/ha & 10940 & 13500 & 13000 & 8690 & 15040 & 16560 & 16220 & 17370 & 14810 & 11720 \\
\hline $\begin{array}{l}\text { DM yield of whole-crop winter sown } \\
\text { wheat cut for fermented silage }\end{array}$ & kg DM/ha & 15243 & 17336 & 15632 & 14093 & 13854 & 17251 & 16103 & 15079 & 15000 & 16816 \\
\hline $\begin{array}{l}\text { DM yield of spring sown barley harvested } \\
\text { for grain }\end{array}$ & kg DM/ha & 6231 & 6452 & 5857 & 5551 & 6205 & 6282 & 6010 & 6728 & 5942 & 6537 \\
\hline
\end{tabular}

Input price deviations derived from de-trended CSO price index data (CSO 2010a); yield distributions derived from national crop variety evaluation data (DAFF 2010). 
this price series adjustment were interest rates, which tend to return to mean values rather than trend in a particular direction. Therefore, the discrete observed values were used for both deposit and loan interest rates.

\section{Yield data}

Production risk is defined for the purposes of the current study as the year-to-year yield variation of a feed crop, as a result of weather variation and unforeseen crop pests and diseases. Year-to-year variation also extends to variation in nutritional value of feed crops on a given farm. However, given the lack of consistent long-term nutritional value data and the fact that previous studies found that feed cost was more sensitive to variation in DM yield than nutritional value variation (Savoie et al. 1985; O'Kiely et al. 1997), the stochastic analysis of production risk focused solely on DM yields for the purposes of the current study.

For this analysis, GFCM default yield calculations were overridden. The DM yields used were the 10-year (1999-2008 inclusive) control yields for feed crops from variety trials published by the Irish Department of Agriculture, Fisheries and Food (DAFF 2010). The time-period studied was limited to 10 years due to data access difficulties. These trials are conducted annually at seven locations throughout the Republic of Ireland to identify new feed crop cultivars suitable for commercial use. Control yields are calculated as the mean yields (over all sites) of two to three approved commercial cultivars for a particular year. Crop management procedures were maintained at a consistently intensive level across the cultivar testing locations and years. Technological changes to crop management practices were minimal over this time period. Thus, yield fluctuations could be reasonably attributed to year-to-year variation in weather and unforeseen pests and diseases. However, because the control cultivars for some crops were changed every $2-3$ years during this period, it must be borne in mind that some element of the observed yield variation may be due to improved yields of new crop cultivars, as described by Talbot (1984). As the variety trials did not include a low-nitrogen $(\mathrm{N})$ grazed perennial ryegrass sward, the yields for the GG90 sward were predicted from the variety trial yields using the GFCM perennial ryegrass $\mathrm{N}$ response equation (Eqn (5)). The discrete 10-year yield distributions simulated for each of the seven feed crops are shown in Table 2.

$$
\begin{aligned}
\text { DMY }_{\mathrm{GG}}= & \left(-0.0444 \times N^{2}\right)+(38.419 \times N) \\
& +6257.2
\end{aligned}
$$

where $\mathrm{DMY}_{\mathrm{GG}}$ is the annual dry matter yield (kg DM/ ha) of grazed grass and $N$ is the annual rate of fertilizer $\mathrm{N}$ applied (kg/ha).

\section{Feed crop scenario analysis}

The feed crop scenarios in terms of management and non-management factors are generally as described in the Appendix (available online at http://cambridge. journals.org/AGS). The scenarios were: a grazed grass sward receiving $90 \mathrm{~kg}$ inorganic $\mathrm{N}$ fertilizer/ha/yr (GG90), a grazed grass sward receiving $200 \mathrm{~kg}$ inorganic N fertilizer/ha/yr (GG200), two grass silage scenarios using different conservation technologies (GS, primary harvest perennial ryegrass bunker silage; GSB, primary harvest perennial ryegrass baled silage), a whole-crop maize (WCM) silage, a whole-crop wheat (WCW) silage, a BG crop and a purchased rolled barley feed (PRB). Table 3 illustrates the main management scenarios simulated for each of the eight feed crops in the stochastic analysis.

GG90 and GG200 were perennial ryegrass swards rotationally grazed by cattle at a stocking rate of 110 and $170 \mathrm{~kg}$ organic N/ha, respectively. Stocking rate was defined as the annual organic $\mathrm{N}$ excreted by grazing livestock per grassland hectare, as defined by the Nitrates Directive (Anonymous 2006). Fixed costs were constant for the two grazed grass swards (Table 5). The grass silage crops (GS and GSB) had a final spring defoliation date of 31 March and were mowed for silage on 15 May. GS was consequently harvested by a precision-chop forage harvester following a $6 \mathrm{~h}$ wilt. GSB was wilted in situ for $48 \mathrm{~h}$ before baling and wrapping. WCM was sown in late April without the use of polythene mulch. The whole-crop silages and the BGs were all assumed to be sown, managed and harvested at dates deemed most favourable for achieving optimal maturity for the specified harvesting and conservation options (i.e. fermented whole-crop silage for the wheat and maize, and propionic acid treatment for the BG). Fertilizer application rates for all crops were based on the requirements for Irish conditions specified by Coulter \& Lalor (2008). The default purchased feed included as a benchmark for the home-produced feeds in the current analysis was dried, rolled BG, purchased and delivered at a mean price of $€ 170 / \mathrm{t}$ (CSO 2010a). The purchased 
Table 3. Feed crop management scenarios and nutritional values simulated for stochastic analysis

\begin{tabular}{|c|c|c|c|c|c|c|c|c|c|c|c|}
\hline \multirow[b]{2}{*}{ Feed crop } & \multirow{2}{*}{$\begin{array}{l}\text { Month sown } \\
\text { (sward age)* }^{*}\end{array}$} & \multicolumn{3}{|c|}{$\begin{array}{l}\text { Macronutrient } \\
\text { fertilizer } \\
\text { appliedt }\end{array}$} & \multirow{2}{*}{$\begin{array}{l}\text { Month } \\
\text { harvested } \\
\text { or grazed }\end{array}$} & \multirow[b]{2}{*}{ Harvest option } & \multirow{2}{*}{$\begin{array}{l}\text { Treatment/ } \\
\text { processing }\end{array}$} & \multirow[b]{2}{*}{ Storage facility } & \multirow{2}{*}{$\begin{array}{l}\text { DM at } \\
\text { feed-out }\end{array}$} & \multirow{2}{*}{$\begin{array}{l}\text { DMD at } \\
\text { feed-out§ }\end{array}$} & \multirow{2}{*}{$\begin{array}{l}\text { UFV at } \\
\text { feed-out** }\end{array}$} \\
\hline & & $\mathrm{N}$ & $\mathrm{P}$ & $\mathrm{K}$ & & & & & & & \\
\hline GG90 & (7) & 90 & 7 & 8 & Mar-Nov & Grazed & - & - & 174 & 817 & 0.97 \\
\hline GG200 & (7) & 200 & 10 & 15 & Mar-Nov & Grazed & - & - & 174 & 817 & 0.97 \\
\hline GS & $(5)$ & 85 & 16 & 121 & May & $\begin{array}{l}\text { Mowed and } \\
\text { precision-chop }\end{array}$ & Fermented silage & $\begin{array}{l}247 \text { t walled concrete silo } \\
\text { plus effluent tank }\end{array}$ & 217 & 778 & $0 \cdot 86$ \\
\hline GSB & (5) & 85 & 16 & 121 & May & $\begin{array}{l}\text { Mowed, swath } \\
\text { conditioned } \\
\text { and baled }\end{array}$ & Wilted silage & $\begin{array}{l}\text { Stacked on broken } \\
\text { stone surface }\end{array}$ & 324 & 778 & $0 \cdot 86$ \\
\hline WCM & Apr & 130 & 30 & 130 & Oct & Direct-cut & Fermented silage & 534 t walled concrete silo & 320 & 680 & $0 \cdot 75$ \\
\hline WCW & Oct & 180 & 25 & 110 & Aug & Direct-cut & Fermented silage & 534 t walled concrete silo & 400 & 694 & $0 \cdot 69$ \\
\hline BG & Mar & 120 & 25 & 85 & Sep & Combined & $\begin{array}{l}\text { Rolled and propionic } \\
\text { acid treated }\end{array}$ & $\begin{array}{l}100 \text { t roofed concrete } \\
\text { grain store }\end{array}$ & 800 & 883 & $1 \cdot 15$ \\
\hline PRB & - & - & - & - & - & - & - & $\begin{array}{l}100 \text { t roofed concrete } \\
\text { grain store }\end{array}$ & 866 & 883 & $1 \cdot 15$ \\
\hline
\end{tabular}

* Sward age for perennial crops in years.

$+\mathrm{kg} / \mathrm{ha} /$ year.

‡ g DM/kg.

$\S \mathrm{g} / \mathrm{kg} \mathrm{DM}$.

** UFV/kg DM; GG90, grazed perennial ryegrass 90 kg N/ha; GG 200, grazed perennial ryegrass 200 kg N/ha; GS, primary harvest perennial ryegrass bunker silage; GSB, primary harvest perennial ryegrass baled silage. 


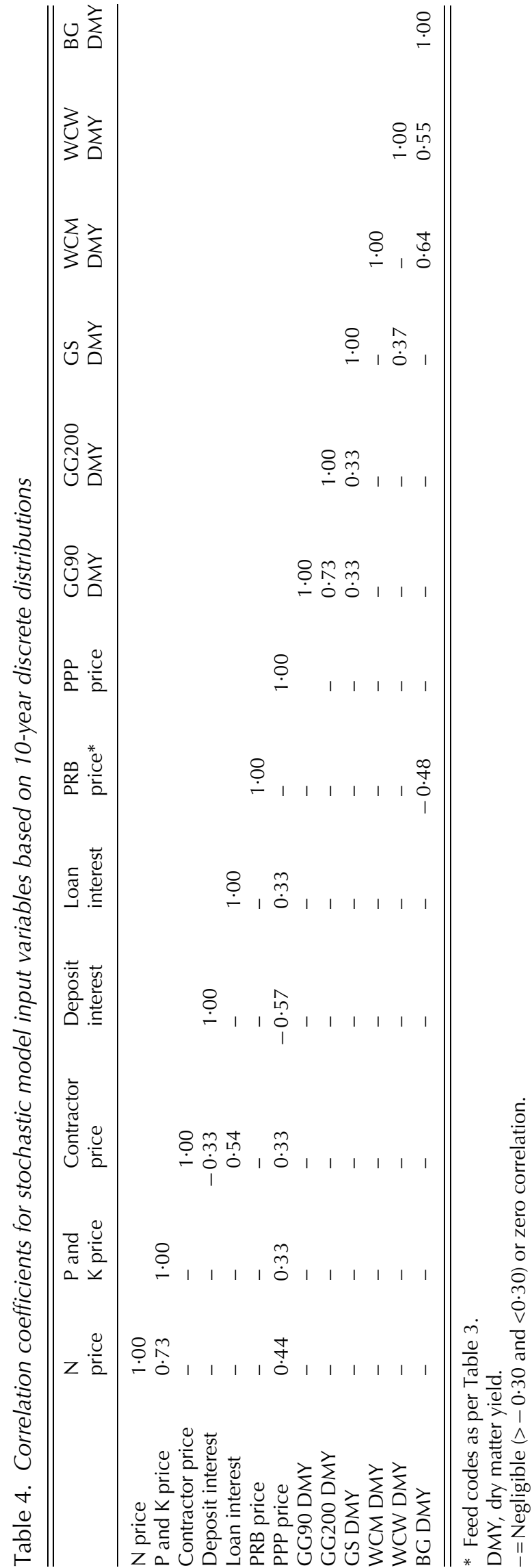

rolled barley price was included as a stochastic variable to quantify the effect of feed market supply and demand on feed cost risk. For the stochastic analysis, all feed cropping scenario parameters except for DM yield and unit price of inputs were assumed to remain constant. All stochastic variables were simulated simultaneously with input variables correlated according to the 10-year dataset (Table 4). There was a strong positive correlation between the price of $\mathrm{P}$ and $\mathrm{K}$ and $N$ fertilizer, between GG90 and GG200 DMY and between WCM and BG DMY. The main default costs for each of the eight feeds are shown in Table 5. For further detail on the crop assumptions, functions and default parameters please refer to the Appendix (available online at http://cambridge.journals.org/AGS).

\section{RESULTS}

Mean cost

With mean TFC expressed on a net energy basis, the feeds ranked from least to most expensive: GG200, GG90, PRB, BG, WCW, WCM, GSB and GS (Table 6). GG200 was the cheapest feed crop at a mean cost of $€ 74 / 1000$ UFV. The more extensively stocked GG90 was $7 \%$ more expensive, while the conserved feeds ranged from $254 \%$ (PRB) to $291 \%$ (WCM) of the cost of GG200. PRB was the least expensive alternative to grazed grass over the 10 years, and was $2 \cdot 5 \%$ cheaper than the home-produced barley.

\section{Total risk}

The CDFs in Fig. 3 indicate the level of TFC risk for each of the eight simulated feeds over the period 1999-2008. Flatter CDFs imply greater riskiness, steeper curves indicate less risky feeds. CDFs to the left are preferred (lower TFC). Some of the CDFs to the right intersect one another, suggesting that the preferred choice among these would depend on the level of risk averseness of the decision maker. Using coefficient of variation (CV) as a measure of total riskiness, the feeds ranked BG, PRB, WCW, GSB, GG90, GG200, GS and WCM from lowest to highest risk (Table 6). The most expensive example of GG200 (95th percentile) was $€ 71 / 1000$ UFV less expensive than the cheapest alternative to GG: a high-yielding WCM crop under a scenario of low input prices (5th percentile) (Table 6). At the 5th percentile WCM was also the only conserved feed that was less expensive than PRB. However, at the 95th percentile, WCM was the most expensive feed. BG exhibited the lowest total 
Table 5. Mean feed costs $€ /$ ha (except where otherwise stated)

\begin{tabular}{llcccc}
\hline \hline Feed* & Fertilizer costt & PPP cost‡ & Contractor cost§ & Fixed costs** & TFC+t \\
\hline GG90 & 109 & - & 52 & 78 & 551 \\
GG200 & 220 & - & 55 & 78 & 667 \\
GS & 268 & 5 & 333 & 67 & 761 \\
GSB & 268 & 5 & 394 & 31 & 783 \\
WCM & 376 & 81 & 579 & 80 & 1672 \\
WCW & 425 & 356 & 585 & 80 & 1858 \\
BG & 302 & 171 & 712 & 60 & 129 \\
PRB $\neq \neq$ & - & - & $8 \cdot 47$ & $9 \cdot 50$ & 217 \\
\hline \hline
\end{tabular}

Feed crop codes as per Table 3.

+ Fertilizer cost includes contractor spreading cost.

¥ PPP cost includes contractor spraying cost.

$\S$ Contractor cost includes crop establishment, harvesting, processing and feed-out operations as well as herding cost for the grazed scenarios.

** Fixed costs include depreciation of fixed assets, including sward establishment and fencing costs for grass crops and storage facility costs for harvested crops.

t+ TFC includes LC of $€ 300 / h a / y r$.

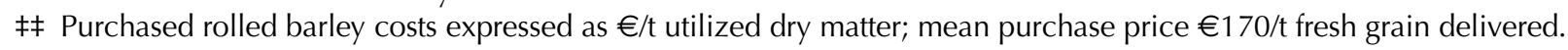

risk (CV 0.063), just below that of PRB (CV 0.064), which incurred no direct exposure to yield risk.

Price risk

The feeds least sensitive to price risk were GG90, GG200, WCW and BG (Table 6). The feeds most sensitive to input price fluctuations were PRB, GS and GSB. PRB was most sensitive to the market price of rolled barley because purchase price comprises 0.895 of PRB TFC. The greatest component of total price risk was $\mathrm{P}$ and $\mathrm{K}$ price, generally followed by contractor price, and then $\mathrm{N}$ price, for all home-produced feed crops except for GG90 and GG200, which were more sensitive to $\mathrm{N}$ than contractor price (Table 7 ). All the feeds exhibited low levels of sensitivity to price risk of the other inputs examined (namely PPP price, deposit interest rate and loan interest rate).

Yield risk

Yield variability was the greatest risk affecting TFC of the seven home-produced feeds in the current analysis (Tables 6 and 7). The feeds least sensitive to yield risk were GSB and BG. Both feeds incur a high proportion of yield-dependent costs within TFC. All bale-related costs (baling, wrapping and handling) are a direct function of yields, and similarly the substantial rolling and propionic acid treatment of BG are costed on a per tonne basis. Conversely, high proportions of fixed costs and area-dependent variable costs within TFC can increase the exposure to yield risk because lower-than-average yields result in considerable 'under-capacity costs' (Shoup 2004). The feeds most sensitive to yield risk were GG90, GG200 and WCM.

\section{DISCUSSION}

\section{Mean TFC relativity}

As expected, the greater yields of grass utilized under the GG200 scenario than the more extensive GG90 scenario resulted in a lower mean cost per unit net energy for GG200. The lower feed cost was achieved via increased stocking rate and $\mathrm{N}$ application, because the area-dependent LC and fixed costs were diluted by the greater output.

Grazed perennial ryegrass was, as expected, the cheapest feed in the analysis. However, its production is seasonal and utilization is poor during periods of soil waterlogging. To address this imbalance, it has been proposed that grass should be costed as a 'full-year feed' by including the cost of a conservation harvest required to feed a proportion of the grazing livestock over the following winter (Finneran et al. 2010a). Taking conservation harvests during the period of peak summer grass production is an aid to good grassland management because surplus grass is not wasted. This complementary benefit to grazed grass of a conservation harvest should be acknowledged when comparing the cost of grass silages with other conserved feeds. Further GFCM studies will address this issue.

The substantial cost advantage of grazed perennial ryegrass and its predominance in pasture-based ruminant production systems dictate that it is beneficial 
Table 6. TFCs (€1000/UFV) stochastic analysis results

\begin{tabular}{|c|c|c|c|c|c|c|c|c|}
\hline & Feed* & Min & Mean & Max & S.D. & $\mathrm{CV}$ & $P=0.05$ & $P=0.95$ \\
\hline \multirow[t]{8}{*}{ Total risk } & GG90 & 69 & 80 & 93 & $5 \cdot 67$ & $0 \cdot 071$ & 72 & 89 \\
\hline & GG200 & 64 & 74 & 87 & $5 \cdot 36$ & 0.072 & 66 & 83 \\
\hline & GS & 171 & 215 & 269 & $20 \cdot 27$ & 0.094 & 185 & 250 \\
\hline & GSB & 176 & 210 & 252 & $14 \cdot 52$ & 0.069 & 188 & 236 \\
\hline & WCM & 143 & 206 & 309 & $40 \cdot 23$ & $0 \cdot 195$ & 154 & 280 \\
\hline & WCW & 174 & 204 & 239 & $13 \cdot 58$ & 0.067 & 183 & 226 \\
\hline & BG & 165 & 194 & 226 & $12 \cdot 18$ & 0.063 & 175 & 214 \\
\hline & PRB & 167 & 189 & 211 & $12 \cdot 09$ & $0 \cdot 064$ & 170 & 208 \\
\hline \multirow[t]{8}{*}{ Price risk } & GG90 & 77 & 80 & 82 & $1 \cdot 15$ & $0 \cdot 014$ & 78 & 81 \\
\hline & GG200 & 71 & 74 & 77 & $1 \cdot 35$ & $0 \cdot 018$ & 72 & 76 \\
\hline & GS & 195 & 214 & 232 & $7 \cdot 65$ & $0 \cdot 036$ & 201 & 226 \\
\hline & GSB & 191 & 209 & 227 & $7 \cdot 34$ & 0.035 & 197 & 221 \\
\hline & WCM & 184 & 199 & 214 & $6 \cdot 19$ & 0.031 & 189 & 209 \\
\hline & WCW & 191 & 203 & 215 & $4 \cdot 84$ & $0 \cdot 024$ & 195 & 211 \\
\hline & $\mathrm{BG}$ & 179 & 193 & 207 & $5 \cdot 52$ & $0 \cdot 029$ & 184 & 202 \\
\hline & PRB & 168 & 189 & 210 & $12 \cdot 08$ & 0.064 & 170 & 208 \\
\hline \multirow[t]{8}{*}{ Yield risk } & GG90 & 71 & 80 & 90 & $5 \cdot 56$ & $0 \cdot 070$ & 72 & 89 \\
\hline & GG200 & 66 & 74 & 84 & $5 \cdot 20$ & $0 \cdot 070$ & 67 & 83 \\
\hline & GS & 186 & 215 & 251 & $18 \cdot 73$ & 0.087 & 188 & 247 \\
\hline & GSB & 191 & 210 & 234 & $12 \cdot 48$ & $0 \cdot 060$ & 192 & 231 \\
\hline & WCM & 152 & 206 & 293 & $39 \cdot 56$ & $0 \cdot 192$ & 155 & 280 \\
\hline & WCW & 183 & 204 & 227 & $12 \cdot 63$ & 0.062 & 185 & 224 \\
\hline & BG & 176 & 193 & 213 & $10 \cdot 76$ & 0.056 & 177 & 211 \\
\hline & PRB & 189 & 189 & 189 & - & - & - & - \\
\hline
\end{tabular}

* Feed codes as per Table 3.

S.D., standard deviation; CV, coefficient of variation.

Table 7. Regression coefficients for TFC against input price risks and yield risk

\begin{tabular}{|c|c|c|c|c|c|c|c|c|}
\hline & GG90* & GG200 & GS & GSB & WCM & WCW & BG & PRB \\
\hline $\mathrm{N}$ price & $0 \cdot 057$ & $0 \cdot 111$ & $0 \cdot 059$ & $0 \cdot 079$ & $0 \cdot 013$ & $0 \cdot 054$ & $0 \cdot 051$ & - \\
\hline $\mathrm{P}$ and $\mathrm{K}$ price & $0 \cdot 195$ & $0 \cdot 226$ & $0 \cdot 358$ & $0 \cdot 475$ & $0 \cdot 149$ & $0 \cdot 328$ & $0 \cdot 390$ & - \\
\hline Contractor price & $0 \cdot 007$ & $0 \cdot 011$ & $0 \cdot 107$ & $0 \cdot 173$ & $0 \cdot 060$ & $0 \cdot 129$ & $0 \cdot 226$ & $0 \cdot 014$ \\
\hline Deposit interest & $0 \cdot 007$ & $0 \cdot 008$ & $0 \cdot 015$ & $0 \cdot 014$ & $0 \cdot 007$ & $0 \cdot 030$ & $0 \cdot 027$ & - \\
\hline Loan interest & $0 \cdot 000$ & $0 \cdot 000$ & $0 \cdot 015$ & $0 \cdot 000$ & $0 \cdot 005$ & $0 \cdot 013$ & $0 \cdot 010$ & $0 \cdot 011$ \\
\hline PRB price & - & - & - & - & - & - & - & 0.999 \\
\hline PPP price & - & - & - & - & $0 \cdot 000$ & $0 \cdot 018$ & $0 \cdot 015$ & - \\
\hline GG90 DMY & $-0 \cdot 978$ & - & - & - & - & - & - & - \\
\hline GG200 DMY & - & -0.967 & - & - & & - & - & - \\
\hline GS DMY & - & - & -0.921 & $-0 \cdot 857$ & - & - & - & - \\
\hline WCM DMY & - & - & - & - & -0.968 & - & - & - \\
\hline WCW DMY & - & - & - & - & - & -0.929 & - & - \\
\hline BG DMY & - & - & - & - & - & - & $-0 \cdot 882$ & - \\
\hline R-squared & 0.996 & 0.996 & 0.993 & 0.993 & $0 \cdot 969$ & 0.997 & 0.998 & $1 \cdot 000$ \\
\hline
\end{tabular}

* Feed codes as per Table 3.

DMY, dry matter yield.

to express the cost of alternative feeds relative to the cost of grass. The relative cost of grain feeds to grazed grass was lower in this analysis than that found by
O'Kiely et al. (1997). However, the relative costs of silages (grass, wheat and maize) to grazed grass were very similar in both studies. 
As a result of the greater contractor and total costs per hectare associated with baled grass silage relative to a bunker-ensiled grass crop (Table 5), it was somewhat surprising that GSB was on average cheaper than GS for the 10 years' yields simulated. This lower cost for GSB is mainly due to two factors. Firstly, GSB incurs a relatively low proportion of fixed costs and area-dependent variable costs, because most costs are incurred on a 'per bale' rather than a 'per hectare' basis. In contrast, harvesting costs for GS are area dependent and fixed costs are greater, due to the use of concrete silos. Secondly, because bales are wrapped and fed out individually, greater DM conservation and feed-out efficiencies are attributed to bales relative to bunker silages. The combination of these factors appears to more than offset the additional harvesting and feed-out cost of bales at the mean yield in the current analysis. Previous work has shown that at higher mean yields ( $>6 \mathrm{t} \mathrm{DM} / \mathrm{ha})$, the fixed costs and areadependent costs of a bunker-ensiled crop are diluted to the extent that bunker silage becomes a less expensive technology than bales (Finneran et al. 2010b).

Maize silage and wheat silage were 4 and $5 \%$ less expensive on average than grass silage. This provides some explanation for the increase in area of these whole-crop silages over the past decade in Ireland (CSO 2010b). This increase is likely to be due to a combination of the mean cost advantage of wheat and maize silages and farmer perceptions of the differing risk factors affecting each of these feeds as discussed below.

The lower mean cost of purchased barley relative to the home-produced BG suggests an element of market failure for feed barley producers in Ireland, in that the market price did not meet the production cost of BG over this time period. This shows that on average, for the assumptions used in this analysis, BG was more expensive to grow than to purchase. This mirrors the results of optimization modelling by Neal et al. (2007), which often favoured the purchase of cereal grains over home production in Australia.

\section{TFC risk}

As illustrated in Fig. 3, WCM exhibited the maximum risk of any of the feeds in this analysis. This is not unexpected in that maize is a relatively new crop to Ireland and until recently, climatic conditions had been described as marginal for maize (Crowley 2005). In recent years, new cultivars have been developed that mature earlier, requiring fewer heat units to reach maturity, peak cob and whole-crop yields. Consequently, yields have been increasing at a greater rate for maize than for any other crop in the national variety testing programme over the past 10 years. Therefore, some of the 'yield risk' (e.g. above the 60th percentile; Fig. 3) attributed to maize in this analysis may be a reflection of the inherently lower-yielding cultivars sown in the earlier part of the decade studied. In addition, the technology of sowing maize under polythene film is now widespread in inland and northern regions of Ireland and has significantly increased whole-crop yields (Crowley 2005). This technology could not be simulated in the current analysis as no polythene-covered plots were included in the variety trials for the first 5 years of the time period analysed for the current study. Therefore, the maize yields used for the current analysis were from crops sown without plastic cover. The wide range of TFC values observed for maize meant that it could be both the cheapest alternative to grazed grass (at the 5th percentile), and the most expensive (at the 95th percentile; Fig. 3). Therefore, the level of risk that an individual farmer could tolerate would be a key factor if making a decision between planting maize or an alternative crop.

WCW and WCM maintained very similar mean costs in the current analysis (Table 6). On average, WCM was $1.1 \%$ more expensive than WCW. However, WCM exhibited a TFC CV of $19 \cdot 5$ as against 0.067 for WCW, primarily due to the greater yield risk incurred by the maize crop. The higher yield risk of WCM is due to the greater weather risk associated with maize than wheat, because of the inherent greater heat unit requirements for the maize plant to attain maturity. These results maintain similar relative yield variability values to those documented by Talbot (1984), who reported CV values of 0.18 and 0.26 for wheat and maize yields respectively, using 13 years variety trial data in the UK. Wheat cultivars have been selected for suitability for Irish conditions for a much longer time period than maize and consequently technological improvements in management and genetics have improved both yield volume and yield consistency over many years. Therefore, the increasing area sown for WCW and WCM in recent years in Ireland may be due to the relative consistency of yields for wheat, and the high yields of maize achievable under favourable weather conditions and the use of newer, higheryielding cultivars and/or polythene mulch technology.

As a technology for ensiling primary harvest perennial ryegrass, GS is less expensive than GSB below the 20th percentile because while the yield-dependent 
TFC of GSB is advantageous at lower yields, at yields greater than $5.7 \mathrm{t} \mathrm{DM} / \mathrm{ha}$ (such as observed in 2000 and 2001; Table 3), the more area-dependent GS is the cheaper option. At lower GS yields, the fixed cost of the concrete bunker and the area-dependent contractor charge for harvesting greatly increase TFC per unit of feed due to the problem of over-capacity. The reduced yield risk factor associated with GSB relative to GS partially explains the increasing popularity of an apparently more expensive feed (GSB) in Ireland in recent years.

BG was the least risky feed in the current analysis (Table 6), due in part to the yield-dependent conservation and feed-out costs discussed above and also the lowest yield variability of any of the harvested crops. This is in agreement with the work of Talbot (1984), who noted that low-yield variability was a feature of lower-yielding crops such as spring barley.

Perhaps the most striking of all the results is the fact that, besides being the least expensive alternative to grazed grass at mean cost, PRB also exhibited a relatively low level of TFC risk. While WCM was less expensive than PRB below the 35th percentile, the overall CV value of PRB was lower than that of any home-produced feed except for BG. This leads one to the conclusion that greater TFC risk is incurred by growing feeds than by purchasing them on the open market. The cost of PRB, being a more stable, energydense feed and therefore suited to prolonged storage and international trade, is understandably less sensitive to domestic price and yield risks than the other less stable or tradable feeds in this analysis. Although rolled barley cannot be fed as the sole component of a ruminant diet, it is generally a primary constituent of concentrate feed mixes. It appears that, assuming feed trading prices maintain the trend of the past decade, purchase rather than growing of conserved feed could be the most effective risk reducing strategy for a ruminant livestock farmer. However, purchased feed prices have become much more variable in recent years (2006-2010; CSO 2010a) and this market volatility will be the key factor in determining the relative riskiness of purchasing rather than home production in the future.

\section{General implications}

Risk quantification is an important consideration for farmers assessing a feeding strategy decision. The following discussion points highlight some of the most important considerations when deriving farm-level implications from the results of this analysis.

1. The time period examined in the current analysis included the commodity price spike in 2007/08. The considerable increase in $\mathrm{P}$ and $\mathrm{K}$ fertilizer price from 2007 to 2008 (Table 3) represented an inflation rate 36 times greater than that observed over the previous 10 years (1998-2007). In spite of this, yield risk was of a much greater magnitude than input price risk for all feed crops over the time period examined (Table 6). This result had been indicated but not quantified by the findings of previous authors (Savoie et al. 1985; Coyle 1992; O'Kiely et al. 1997; Neal et al. 2007). Therefore, although input price volatility has increased during the past decade (CSO 2010a; USDA 2010), yield remains the key variable driving feed crop cost and risk.

2. The yield distributions used in the current analysis were obtained from intensively managed trials in multiple locations and enjoying a high level of management input. It can therefore be assumed that on more extensively managed, single-location farms, inter-annual yield variability would be much greater than that observed in the aggregated time series distributions used here (Coyle 1992; Just \& Weninger 1999; Rudstrom et al. 2002). This implies that greater TFC ranges for all feed crops would occur on individual farms relative to the national mean values presented in the current analysis.

3. The price and yield variation simulated represented the 'unpredictable and uncontrollable' elements of feed crop TFC. They were defined using data collected at a national level. At individual farm level 'extreme' risks such as fires, prolonged droughts or flooding would pose significant but rare risks to feed crop TFC. These risks were beyond the scope of the current study but could be accounted for using an approach such as that used by Mosnier et al. (2009), who quantified the risks of large yield and price shocks for suckler beef systems in France.

4. Because contractor charges were assumed for all cropping and feed-out operations, farms using owned machinery may incur lower variable costs than those quoted in the current paper. The two main problems that may arise when using owned machinery, as described by Shoup (2004), are machinery over-capacity resulting in fixed cost inefficiencies and under-capacity resulting in timeliness-related crop losses. Complex machinery assumptions relating to cost, age, work rate and 
efficiency are avoided by assuming contractor use for all operations. However, the assumption that no timeliness-related crop losses occur when using a contractor is questionable (Gunnarsson et al. 2009).

5. On individual farms, multi-cropping is commonly practised, whereby multiple feed crops are grown in any one year, thereby distributing annual feed cost risk across the different crops. However, while such a strategy would reduce TFC risk at wholefarm level, the level of risk reduction is limited because, as the results of the current study showed (results not presented) TFC risk was strongly positively correlated across the home-produced feed crops.

6. The main assumption underpinning the stochastic analysis is that previously observed prices and yields are a reasonable guide to current or future values. This assumption can be reasonably well defended as regards crop yields, with the noted allowances made for technological improvements. Crop yields are unlikely to decrease in the absence of widespread disease or pest problems or unfavourable changes in climate, and unlikely to increase in the absence of technological changes. However, the assumption that historic price variability can serve as a guide to future price variability may be less robust. Recent periods of rapid energy price inflation followed by deflation have added uncertainty to the challenge of predicting future price risk (USDA 2010).

\section{CONCLUDING COMMENTS}

As livestock production systems also involve numerous sequential processes following on from the production and utilization of the feed, and each with their own cost and risks, whole-farm analysis would be the most appropriate technique to evaluate and compare home-produced feeds. Ideally, feed cost would be expressed per unit of product; e.g. beef, milk, etc. The feed cost and risk information derived from the use of the GFCM can form a valuable input to such a whole farm analysis exercise.

The current study has indicated some management strategies that can be employed to minimize exposure to the uncontrollable risks posed by unfavourable weather and unforeseen pests and diseases. The analysis has shown that those feed crops requiring investment in fixed facilities incur greater exposure to yield risk than feed crops incurring a lesser proportion of fixed costs (e.g. GS v. GSB). The substantial cost advantage of grazing as a means of feed utilization is highlighted by the relatively low cost of grazed grass in the current study.

The finding that purchased rolled barley was the least expensive and also a low-risk alternative to grazed grass raises questions as to the economic logic for home production of conserved feeds when input price and yield risk are considered. It could be inferred from these results that a ruminant livestock farmer could have reduced exposure to feed cost risk by purchasing BG, thereby transferring the greatest burden of risk to the barley producer. It remains to be seen how this dynamic will change under future global scenarios of growing animal and human feed demand and increasingly volatile energy prices.

The GFCM is unique as a powerful analytical tool to examine the interactions of biological, management and market factors on feed crop cost. Risk quantification through the use of stochastic analysis in the model strengthens the GFCM outputs by indicating the relative sensitivity of the different feed crops to the various risk factors outside the control of an individual farmer. Multiple feed crop production, utilization and economic datasets have been brought together, permitting a novel quantification of the complex dynamic relationships constantly evolving between the farmer, technology and economic and biological risk.

\section{SUPPLEMENTARY MATERIAL}

The appendix is available online as supplementary material at http://journals.cambridge.org/AGS

The authors acknowledge the financial support of Walsh Fellowship funding to E. Finneran. The authors would also like to thank D. Grogan, B. O'Reilly and the staff of the Irish Department of Agriculture, Fisheries and Food for providing the crop yield data.

\section{REFERENCES}

Anonymous (2006). European Communities (Good Agricultural Practice for Protection of Waters) Regulations 2006. Statutory Instrument Number 378/2006. Dublin: Irish Statute Book, Office of the Attorney General.

Archer, J. A., Richardson, E. C., Herd, R. M. \& Arthur, P. F. (1999). Potential for selection to improve efficiency of feed use in beef cattle. Australian Journal of Agricultural Research 50, 147-162.

Belasco, E.J., Taylor, M.R., Goodwin, B. K. \& Schroeder, T.C. (2009). Probabilistic models of yield, 
price, and revenue risks for fed cattle production. Journal of Applied Agricultural Economics 41, 91-105.

Connolly, L., Kinsella, A., Quinlan, G. \& Moran, B. (2010). National Farm Survey 2009. Athenry, Republic of Ireland: Teagasc.

Coulter, B. S. \& Lalor, S. (2008). Major and Micro Nutrient Advice for Productive Agricultural Crops. Johnstown Castle, Co. Wexford, Republic of Ireland: Teagasc.

COYLE, B. T. (1992). Risk aversion and price risk in duality models of production: a linear mean-variance approach. American Journal of Agricultural Economics 74, 849859.

Cros, M. J., Duru, M., Garcia, F. \& Martin-Clouaire, R. (2004). Simulating management strategies: the rotational grazing example. Agricultural Systems 80, 23-42.

Crowley, J. G. (2005). Effect of Variety, Sowing Date and Photo-degradable Plastic Cover on the Yield and Quality of Maize Silage. End of Project Report 4726. Crops Research Centre, Oak Park, Carlow, Republic of Ireland: Teagasc.

CSO (2010a). Agricultural Input and Output Absolute Prices: By Month and Statistic. Dublin, Republic of Ireland: Central Statistics Office. Available online at http://cso.ie/ px/pxeirestat/database/eirestat/Agricultural Input and Output Absolute Prices/Agricultural Input and Output Absolute Prices_statbank.asp?SP=Agricultural Input and Output Absolute Prices\&Planguage $=0$ (Verified 22 June 2011).

CSO (2010b). Crop Yield by Type of Crop, Year and Statistic. Dublin, Republic of Ireland: Central Statistics Office. Available online at http://cso.ie/px/pxeirestat/database/ eirestat/Agriculture Area Used and Crop Production/ Agriculture Area Used and Crop Production_statbank. asp? $\mathrm{SP}=$ Agriculture Area Used and Crop Production\& Planguage $=0$ (Verified 22 June 2011).

DAFF (2010). Publications and Information about Crop Variety Evaluation (CVE). Dublin, Republic of Ireland: Department of Agriculture, Fisheries and Food. Available online at http://www.agriculture.gov.ie/farmingsectors/ crops/cropvarietyevaluationcve/publicationsinformation aboutcropvarietyevaluationcve2010/ (verified 22 June 2011).

Dobos, R. C., Ashwood, A. M., Moore, K. \& Youman, M. (2004). A decision tool to help in feed planning on dairy farms. Environmental Modelling and Software 19, 967974.

Finneran, E., Crosson, P. \& Wallace, M. (2010a). The impact of spring grazing and harvest date on the total forage costs of an integrated grazed and conserved perennial ryegrass sward. In Advances in Animal Biosciences: Food, Feed, Energy and Fibre from Land - a Vision for 2020. Proceedings of the British Society of Animal Science and the Agricultural Research Forum, p. 102. Cambridge, UK: Cambridge University Press.

Finneran, E., Crosson, P., O'Kiely, P., Shalloo, L., Forristal, D. \& WallaCe, M. (2010b). Simulation modelling of the cost of producing and utilising feeds for ruminants on Irish farms. Journal of Farm Management 14, 93-117.

Fluck, R. C. \& PeArt, R. M. (2004). Fixed and variable costs of machinery and facilities. In Agricultural Systems
Management: Optimizing Efficiency and Performance (Eds W. D. Shoup \& R. M. Peart), pp. 55-70. New York: CRC Press.

Gunnarsson, C., Spörndly, R., Rosenqvist, H., de Toro, A. \& Hansson, P. A. (2009). A method of estimating timeliness costs in forage harvesting illustrated using harvesting systems in Sweden. Grass and Forage Science 64, 276-291.

Hardaker, J. B., Huirne, R. B. M., Anderson, J. R. \& Lien, G. (2004). Coping with Risk in Agriculture. Wallingford, Oxfordshire, UK: CAB International.

JARRIGE, R. (1989). Ruminant Nutrition: Recommended Allowances and Feed Tables. Paris, France: INRA.

Jones, J. W., Hoogenboom, G., Porter, C. H., Boote, K. J., Batchelor, W. D., Hunt, L. A., Wilkens, P. W., Singh, U., GiJSMAN, A. J. \& Ritchie, J. T. (2003). The DSSAT cropping system model. European Journal of Agronomy $\mathbf{1 8}$ 235-265.

Just, R. E. \& Weninger, Q. (1999). Are crop yields normally distributed? American Journal of Agricultural Economics 81, 287-304.

KaY, R. D. \& Edwards, W. M. (1994). Farm Management. New York, London: McGraw-Hill.

Lien, G., Hardaker, J. B. \& Flaten, O. (2007). Risk and economic sustainability of crop farming systems. Agricultural Systems 94, 541-552.

McCall, D. G. \& Clark, D. A. (1999). Optimized dairy grazing systems in the northeast United States and New Zealand. II. System analysis. Journal of Dairy Science 82, 1808-1816.

McCown, R. L., Hammer, G. L., Hargreaves, J. N. G., HolzWorth, D.P. \& Freebairn, D. M. (1996). APSIM: a novel software system for model development, model testing and simulation in agricultural systems research. Agricultural Systems 50, 255-271.

Mosnier, C., Agabriel, J., Lherm, M. \& Reynaud, A. (2009). A dynamic bio-economic model to simulate optimal adjustments of suckler cow farm management to production and market shocks in France. Agricultural Systems 102, 77-88.

Neal, M., Neal, J. \& Fulkerson, W. J. (2007). Optimal choice of dairy forages in Eastern Australia. Journal of Dairy Science 90, 3044-3059.

O'Kiely, P., Moloney, A. P., Killen, L. \& Shannon, A. (1997). A computer program to calculate the cost of providing ruminants with home-produced feedstuffs. Computers and Electronics in Agriculture 19, 23-36.

O'Mahony, J. \& O'Donovan, T. (2010). Crops Costs and Returns. Oak Park, Co., Carlow, Republic of Ireland: Teagasc.

Pannell, D. J., Malcolm, B. \& Kingwell, R. S. (2000). Are we risking too much? Perspectives on risk in farm modelling. Agricultural Economics 23, 69-78.

Qureshi, M. E., Harrison, S. R. \& Wegener, M. K. (1999). Validation of multicriteria analysis models. Agricultural Systems 62, 105-116.

Rudstrom, M., Popp, M., Manning, P. \& Gbur, E. (2002). Data aggregation issues for crop yield risk analysis. Canadian Journal of Agricultural Economics 50, 185-200.

Savole, P., Parsch, L.D., Rotz, C.A., Brook, R. C. \& BLACK, J.R. (1985). Simulation of forage harvest and 
conservation on dairy farms. Agricultural Systems 17, 117-131.

Shaffer, M. J., Bartling, P. N. S. \& Ascough, J. C. (2000). Object-oriented simulation of integrated whole farms: GPFARM framework. Computers and Electronics in Agriculture 28, 29-49.

Shalloo, L., Dillon, P., O'Lloughlin, J., Rath, M. \& WALLACE, M. (2004). Comparison of a pasture-based system of milk production on a high rainfall, heavy-clay soil with that on a lower rainfall, free-draining soil. Grass and Forage Science 59, 157-168.

Shoup, W. D. (2004). Reliability of agricultural systems. In Agricultural Systems Management: Optimizing
Efficiency and Performance (Eds W. D. Shoup \& R.M. Peart), pp. 19-36. New York: CRC Press.

TALBOT, M. (1984). Yield variability of crop varieties in the U.K. Journal of Agricultural Science, Cambridge 102, 315-321.

USDA (2010). Agricultural Projections to 2019. Washington, DC: USDA.

Visscher, P. M., Bowman, P.J. \& Goddard, M. E. (1994). Breeding objectives for pasture based dairy production systems. Livestock Production Science 40, 123-137.

Wallace, M. T. \& Moss, J. E. (2002). Farmer decision-making with conflicting goals: a recursive strategic programming analysis. Journal of Agricultural Economics 53, 82-100. 